\title{
The Effect of Partial Defoliation, Leaf Position and Developmental Stage of the Vine on Leaf Chlorophyll Concentration in Relation to the Photosynthetic Activity and Light Intensity in the Canopy of Vitis vinifera L. cv. Cabernet Sauvignon.
}

\author{
1)J.J. Hunter and ${ }^{2)}$ J.H. Visser \\ 1) Viticultural and Oenological Research Institute (VORI), Private Bag X5026, 7600 Stellenbosch, Republic of South Africa. \\ 2) Botany Department, University of Stellenbosch, 7600 Stellenbosch, Republic of South Africa. \\ Date submitted: August 1989 \\ Date accepted: October 1989 \\ Key words: Vitis vinifera, Chlorophyll, Defoliation, Developmental stages, Leaf Position, Light intensity, Photosynthesis.
}

\begin{abstract}
The effect of partial defoliation and leaf position on leaf chlorophyll concentration in relation to the photosynthetic activity and light intensity in the canopy of Vitis vinifera $\mathbf{L}$. cv. Cabernet Sauvignon was investigated at berry set, pea size, véraison and ripeness stages. The leaves of the severely defoliated vines appeared to contain the highest chlorophyll concentration. In general, chlorophyll a decreased as the leaves were situated progressively deeper into the canopy. No consistent relationship between chlorophyll concentration, light intensity and photosynthetic activity could be found for the different leaf positions. However, to obtain leaves that photosynthesize optimally, the amount and time of leaf removal in the grapevine canopy must be carefully planned.
\end{abstract}

Uncertainty exists whether an increase or decrease in chlorophyll concentration is associated with fluctuations in photosynthetic activity. Gabrielsen (1948) stated that the full effect of chlorophyll concentration can only be observed in weak light where photosynthesis is proportional to light intensity. According to Hesketh (1963), chlorophyll concentration was not critical in determining the differences in photosynthetic activity observed among species.

Although photosynthesis was not linearly related to chlorophyll concentration (Marini \& Marini, 1983), higher chlorophyll concentrations and lower photosynthetic activities were found for interior-canopy leaves when compared to peripheral, sun-exposed peach (Prunus persica) leaves (Kappel \& Flore, 1983; Marini \& Marini, 1983). According to Sestak (1966), changes in the density and length of irradiation are the main factors opposing a linear relationship between chlorophyll content and photosynthetic rate.

Photosynthetic activity decreased in aged leaves, while chlorophyll concentration continued to increase (Kriedemann, 1968; Anderson \& Brodbeck, 1988) or decreased only slightly (Sestak, 1966; Kriedemann, Kliewer \& Harris, 1970) with leaf age after full expansion. Fruiting had variable effects on photosynthesis (Schaffer, Barden \& Williams, 1986). According to Schaffer et al. (1986), chlorophyll concentration in old and young leaves of deblossomed strawberry (Fragaria $\mathrm{x}$ ananassa Duch.) plants was generally higher than in corresponding leaves of fruiting strawberry plants. Hofäcker (1978), however, reported increases in chlorophyll concentration as well as photosynthesis for bearing Riesling vines compared to vines bearing no grapes.

Reducing the size of the source relative to the sink resulted in an increase in the photosynthetic efficiency of the leaves (Buttrose, 1966; May, Shaulis \& Antcliff, 1969; Kliewer \& Antcliff, 1970; Kriedemann, 1977; Hofäcker, 1978; Johnson, Weaver \& Paige, 1982; Hunter \& Visser, 1988 b, 1988 c). Hofäcker (1978) also found an increase in chlorophyll con- centration in the leaves of potted Riesling vines with increasing levels of defoliation. An increase in chlorophyll concentration was suggested as a reason for the photosynthetic rejuvenation or inhibited leaf senescence induced by partial defoliation (Wareing, Khalifa \& Treharne, 1968; Hodgkinson, 1974).

The grapevine canopy consists of leaves of different ages, which are subjected to variable light intensities during the entire growth season (Hunter \& Visser, 1988c). According to Boardman (1977), a leaf's photosynthetic productivity is primarily governed by its position in the plant canopy. It would, therefore, be of interest to determine the changes in chlorophyll concentration of the leaves as well as the relationship, if any, with the different photosynthetic activities observed by Hunter \& Visser (1988c), especially when partial defoliation was employed. The results may then be used to remove sensibly leaves making a lesser contribution to the photosynthetic capacity of the vine, thus altering the vine's canopy to conditions favourable for maximum photosynthesis of the remaining leaves as well as the production of high quality grapes. Therefore, the effect was studied of partial defoliation on the chlorophyll concentration of Cabernet Sauvignon leaves, situated in different positions in the canopy, in relation to their photosynthetic activity and radiation exposure at berry set, pea size, véraison and ripeness stages.

\section{MATERIALS AND METHODS}

\section{Experimental vineyard}

An eight-year-old Vitis vinifera L. cv. Cabernet Sauvignon, clone $4 / R 46$, vineyard at the experimental farm of the Viticultural and Oenological Research Institute near Stellenbosch in the Western Cape was used. The cultivar was grafted onto rootstock 99 Richter, clone 1/30/1. Vines were planted (3,0 x 1,5 m spacing) on a Clovelly soil (MacVicar et al., 1977 ) and trained onto a $1,5 \mathrm{~m}$ slanting trellis as described by Zeeman (1981). Further details of the experimental vineyard used were given by Hunter \& Visser (1988a).

Acknowledgements: The technical assistance of D.J. le Roux, C.P. Visser, W.J. Groenewald and L.M. Paulse is appreciated. 


\section{Experimental design}

The experiment was laid out as a completely randomised 3 $\mathrm{x} 4 \mathrm{x} 4$ factorial design. The three factors were: defoliation treatments, applied to the whole vine $(0 \%, 33 \%, 66 \%)$; leaves situated at four positions on one shoot per vine (opposite and below the bunches, basal, middle, apical); and developmental stages (berry set, pea sized berry, véraison, ripeness). The basal, middle and apical leaf positions were defined according to leaf number on the shoot (Hunter \& Visser, 1988a). Chlorophyll determinations as well as photosynthesis and photon flux density measurements were done at each leaf position and developmental stage. There were nine replications, comprising one vine per plot, for each of the 48 treatment combinations.

\section{Defoliation treatments}

Different levels of defoliation were implemented from approximately one month after budding. The defoliation treatments consisted of removing the first leaf out of every three leaves (33\%) and removing the first two leaves out of every three leaves $(66 \%)$ starting at the basal end of the shoot. All shoots, including lateral shoots, were treated likewise. Defoliation percentages were maintained until each sampling stage, i.e. leaves emerging after the initial defoliations were removed as described above at approximately monthly intervals.

\section{Measurements}

Photosynthetic activity $\left(\mathrm{mg} \mathrm{CO} / \mathrm{dm}^{2} / \mathrm{h}\right.$ ) and photon flux density $\left(\mathrm{W} / \mathrm{m}^{2}\right)$ were determined as described by Hunter \& Visser (1988c), Leaf areas were determined with a Li-Cor LI 3000 portable area meter.

\section{Chlorophyll determinations}

A modified method of Mackinney (1941) was used for the chlorophyll determinations. After the determination of leaf area and leaf mass, a representative fresh leaf sample of $5 \mathrm{~g}$ was cut into pieces of $1 \mathrm{~cm}^{2}$. The leaf material was added to $100 \mathrm{~cm}^{3} 80 \%$ aqueous acetone containing $0,1 \mathrm{~g} \mathrm{CaCo}_{3}$ and macerated with a Kinematica $\mathrm{Gmbh}$ ultrathorax macerator at room temperature for $60 \mathrm{~s}$ at $10000 \mathrm{rpm}$. The homogenate was left to settle in the dark at $5^{\circ} \mathrm{C}$ for $24 \mathrm{~h}$, after which the sediment was completely discoloured. The final volume was taken as $100 \mathrm{~cm}^{3}$.

The equations used for determination of chlorophyll concentration were as follows (Arnon, 1949):

Chlorophyll $a\left(\mathrm{mg} / \mathrm{dm}^{3}\right)=12,7 \mathrm{~A}_{663}-2,69 \mathrm{~A}_{645}$

Chlorophyll $b\left(\mathrm{mg} / \mathrm{dm}^{3}\right)=22,9 \mathrm{~A}_{645}-4,68 \mathrm{~A}_{663}$

Statistical analyses

A two-way analysis of variance (standard statistical software package of the VORI) was done on the raw data. Statistical analyses for the determination of significant differences between treatment means were done using a Scott-Knott analysis. The same program was used for log transformations, where applicable, and to determine correlation coefficients. Because no significant interactions between defoliation percentage and developmental stage of the vine were found for any of the leaf positions, only the main effects, namely defoliation percentage and developmental stage were considered. The figures, therefore, depict either averages over stages or averages over defoliation treatments, while data over both factors were used to calculate the correlation coefficients provided in the table.

\section{RESULTS AND DISCUSSION}

\section{Chlorophyll concentration}

The severe defoliation treatment (66\%), albeit not significant, resulted in the highest chlorophyll $a$ concentration (Fig. 1). An increase in chlorophyll concentration as a result of defoliation was also found by Hofäcker (1978) and might suggest an inhibition of senescence of the remaining leaves. The chlorophyll $a$ concentration tended to decrease as the leaves were progressively situated deeper into the canopy. At berry set and pea size stages the chlorophyll $a$ as well as chlorophyll $b$ concentration were apparently the highest for the basal and bunch leaves, while from véraison to ripeness stage the middle and apical leaves were the richest in chlorophyll (Fig. 2). The higher chlorophyll concentrations for the interior, recently matured leaves at the early developmental stages confirm the findings of other investigators (Marini \& Marini, 1983; Anderson \& Brodbeck, 1988). As the leaves were progressively situated towards the periphery of the canopy, maximum chlorophyll $a$ and chlorophyll $b$ concentra-

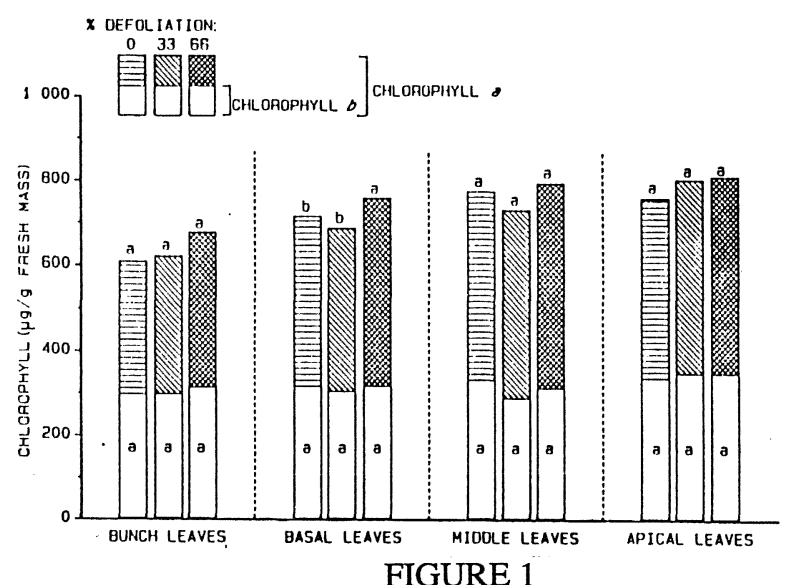

The effect of defoliation on the chlorophyll $a$ and $b$ concentration of leaves in different positions on the shoot. Values represent the means over developmental stages. Vertical bar values designated by the same letter do not differ significantly $(p \leq 0,05)$ for each leaf position.

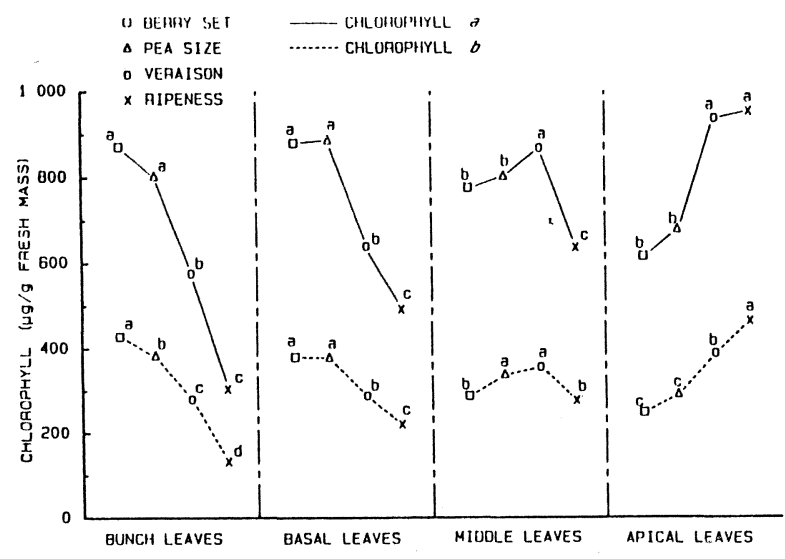

FIGURE 2

The effect of developmental stage of the vine on the chlorophyll $a$ and $b$ concentration of leaves in different positions on the shoot. Values represent the means over defoliation treatments. Values designated by the same letter do not differ significantly $(p \leq 0,05)$ for each leaf position. 
tions were reached later during the growth season, e.g. in the bunch leaves the highest concentrations occurred at berry set, while in the apical leaves maximum concentrations were only reached at ripeness. The variation in chlorophyll concentration observed for the different leaves during the growth season would, therefore, primarily seem to reflect differences in leaf age.

\section{Photosynthetic activity \& light intensity}

The photosynthetic activity $\left(\mathrm{mg} \mathrm{CO}_{2} / \mathrm{dm}^{2} / \mathrm{h}\right)$ of the leaves on the shoot in relation to the photon flux density at the different leaf positions is shown in Fig's. $3 \& 4$. It is evident that photosynthetic activity generally increased upon partial defoliation (Fig. 3). This was fully discussed by Hunter \& Visser (1988c). For the middle and apical leaves, photosynthetic activity increased more than expected with increasing light intensity, suggesting the probable involvement of a nonphotochemical process(es) (Björkman \& Holmgren, 1963; Wareing et al., 1968; Hunter \& Visser, 1988c). The photosynthetic activity as well as photon flux density declined as the leaves were progressively situated deeper into the canopy (Fig. 3), confirming the well-known deleterious effects of interior-canopy shade as well as leaf age on the photosynthetic response of the leaf (Shaulis, Amberg \& Crowe, 1966; Smart, 1973, 1974, 1985; Kriedemann, 1977; Kliewer, 1980; Kappel \& Flore, 1983; Marini \& Marini, 1983; Koblet, 1984).

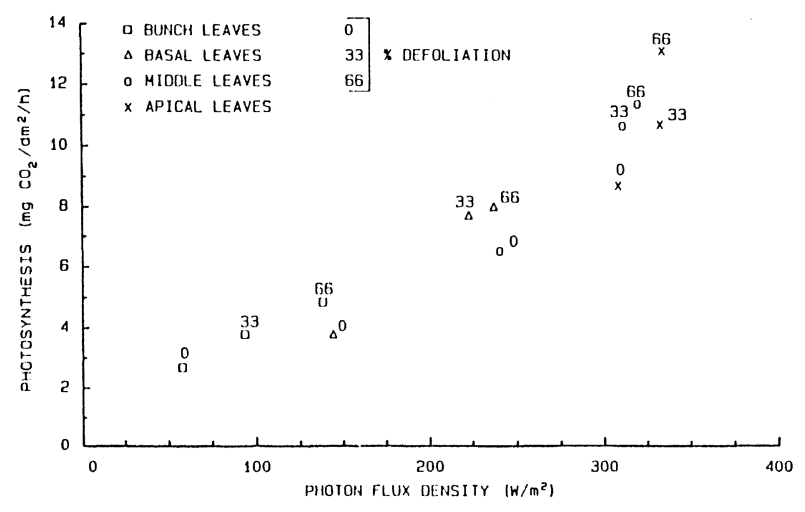

FIGURE 3

The effect of photon flux density on photosynthesis of leaves in different positions on the shoot for different levels of defoliation.

Except for the bunch leaves and basal leaves at ripeness, the photon flux density increased as the growth season progressed (Fig. 4). The photosynthetic activity of the different leaves decreased in general. Possible reasons for the general decline in photosynthetic activity could be the increase in total leaf area of the canopy during the season, resulting in a decreased specific photosynthetic activity of the leaves; an increase in leaf age; a change in chemical content, i.e. an increase in sugar and decreases in amino and organic acid concentrations (Kliewer \& Nassar, 1966; Kriedemann et al., 1970); as well as a decreased demand for assimilates because of a decrease in actively growing vegetative sinks and berry growth. The general increase in photon flux density could have resulted, amongst others, from the lengthening of the shoots on the slanting trellis as the growth season progressed, creating improved light conditions at especially the

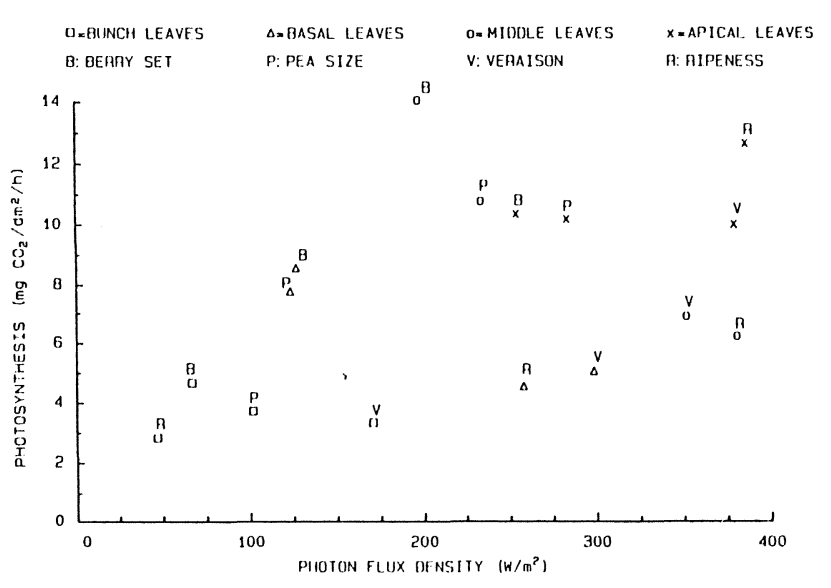

FIGURE 4

The effect of photon flux density on photosynthesis of leaves in different positions on the shoot for different developmental stages of the vine.

outer leaf positions. However, the increasing senescence of the vegetative growth on the vine could have been the overriding factor in the expression of the photosynthetic activity of the leaves.

\section{Chlorophyll $a: b$ ratio}

The effect of defoliation and developmental stage of the vine on the chlorophyll $a: b$ ratio of leaves in different positions on the shoot is shown in Table 1 . Though not statistically significant, the chlorophyll $a: b$ ratio increased in the leaves remaining on the shoot after partial defoliation. This is mainly due to a slight increase in chlorophyll $a$ (Fig. 1). Since chlorophyll $a$ is considered a more exact characteristic of photosynthetic activity (Sestak, 1966), this tendency towards a higher ratio might partly explain the higher photosynthetic activities found for the remaining leaves of the partially defoliated vines (Fig. 3 ). In general, the chlorophyll $a: b$ ratio appears to decline from the middle leaves to the bunch leaves. This is in accordance with the findings for the leaves of plants grown in strong and weak light (Björkman \& Holmgren, 1963), and is also in agreement with the findings of Kriedemann (1968) for leaves of different ages. Although photosynthesis generally decreased during the growth season (Fig. 4), the chlorophyll $a: b$ ratio, however, showed no definite tendency.

\section{Assimilation number}

The effect of defoliation and developmental stage of the vine on the assimilation number ( $\mathrm{mg} \mathrm{CO} / \mathrm{mg}$ chlorophyll/h) of the different leaves is shown in Table 2 . The assimilation number generally increased as a result of partial defoliation, which corresponds to the increase in photosynthetic activity (Fig. 3). This is in agreement with the findings of Hodgkinson (1974), Kriedemann (1977), Hofäcker (1978) and Hunter \& Visser (1988b, 1988c). Compared to the small differences in chlorophyll concentration found between the non-defoliated and partially defoliated vines (Fig. 1), it is evident that chlorophyll concentration could not be the main reason for the increased photosynthetic activity found for the partially defoliated vines (Fig. 3). This substantiates the findings of Gabrielsen (1948), Kriedemann et al. (1970), Hofäcker (1976) and Schaffer et al. (1986) and implies that the light intercepting 
TABLE 1

The effect of defoliation and developmental stage of the vine on the chlorophyll a:b ratio of leaves in different positions on the shoot.

\begin{tabular}{|c|c|c|c|c|c|c|c|c|c|c|c|c|c|c|c|c|}
\hline \multirow{2}{*}{ DEVELOPMENTAL STAGE } & \multicolumn{4}{|c|}{ BUNCH LEAVES } & \multicolumn{4}{|c|}{ BASAL LEAVES } & \multicolumn{4}{|c|}{ MIDDLE LEAVES } & \multicolumn{4}{|c|}{ APICAL LEAVES } \\
\hline & ${ }^{\star} 0$ & ${ }^{\star} 33$ & ${ }^{*} 66$ & Mean & 0 & 33 & 66 & Mean & 0 & 33 & 66 & Mean & 0 & 33 & 66 & Mean \\
\hline Berry set & 1,96 & 2,02 & 2,14 & $2,04^{b}$ & 2,33 & 2,14 & 2,47 & $2,31^{a}$ & 2,61 & 2,73 & 2,77 & $2,70^{a}$ & 2,41 & 2,52 & 2,43 & $2,45^{a}$ \\
\hline Pea size & 2,09 & 2,07 & 2,10 & $2,09^{b}$ & 2,25 & 2,37 & 2,42 & $2,34^{\mathrm{a}}$ & 2,15 & 2,44 & 2,52 & $2,37^{b}$ & 2,37 & 2,17 & 2,43 & $2,33^{a}$ \\
\hline Véraison & 1,94 & 2,06 & 2,14 & $2,05^{b}$ & 2,14 & 2,23 & 2,31 & $2,23^{a}$ & 2,39 & 2,53 & 2,50 & $2,47^{b}$ & 2,45 & 2,45 & 2,35 & $2,42^{a}$ \\
\hline Ripeness & 2,36 & 2,36 & 2,29 & $2,34^{a}$ & 2,23 & 2,34 & 2,17 & $2,25^{a}$ & 2,31 & 2,30 & 2,29 & $2,30^{b}$ & 1,93 & 2,08 & 2,16 & $2,05^{b}$ \\
\hline Mean & $2,09^{A}$ & $2,13^{\mathrm{A}}$ & $2,17^{\mathrm{A}}$ & & $2,24^{A}$ & 2,27 & 2,34 & & $\begin{array}{r}B \\
2,37\end{array}$ & $2,50^{\mathrm{A}}$ & 2,52 & & 2,29 & $2,30^{A}$ & 2,34 & \\
\hline CV (\%) & 7,13 & & & & 6,18 & & & & 6,44 & & & & 5,31 & & & \\
\hline
\end{tabular}

* Percentage defoliation

Values designated by the same letter do not differ significantly $(\mathrm{p} \leq 0,05)$ for each leaf position

ability of the vine leaf is not necessarily closely related to the $\mathrm{CO}_{2}$ assimilating ability.

Hesketh (1963) stated that resistance to $\mathrm{CO}_{2}$ diffusion should increase with increasing fresh mass or thickness and that the relation between photosynthesis and fresh mass per leaf area should, therefore, be negative. However, according to Table 3 the leaves of the $66 \%$ defoliated vines were in general heavier than those of the non-defoliated vines. Hodgkinson (1974) found similar results and suggested that it was probably due to an increase in palisade cell size, which was evidently caused by an accumulation of starch grains in the chloroplasts or increase in chloroplast population per cell. However, accumulation of starch in the chloroplasts can cause a reduced photosynthetic rate (Neales \& Incoll, 1968; Wareing et al., 1968), while only the differences in chlorophyll concentration between the severely defoliated and non-defoliated vines in this study (Fig. 1) might provide support for the latter probability.

Nevertheless, the specific leaf mass apparently decreased from the middle leaves towards the inside of the canopy. This is in accordance with the effect of shading on specific leaf mass (Kappel \& Flore, 1983) and also corresponds to the decrease in assimilation number (Table 2), light intensity and photosynthesis (Fig. 3 ) as well as chlorophyll $a$ : $b$ ratio (Table 1).

The assimilation number generally decreased up to véraison stage, but again increased towards ripeness for all leaf positions, albeit only significantly for the bunch leaves (Table 2). The decrease in assimilation number as the growth season progressed corresponds to the decrease in photosynthesis (Fig. 4) as well as an apparent increase in specific leaf mass (Table 3) and confirms the findings of Kriedemann (1977) and Hunter \& Visser (1988a, 1988b, 1988c). Nevertheless, except for the apical leaves, the apparent increase in assimilation number found from véraison to ripeness stage does not relate to the corresponding photosynthetic activity (Fig. 4).

Total $\mathrm{CO}_{2}$ assimilation rate

The effect of defoliation on the total $\mathrm{CO}_{2}$ assimilation rate (calculated on a total leaf area basis as $\mathrm{mg} \mathrm{CO}_{2} / \mathrm{h}$ ), in relation to the total leaf area $\left(\mathrm{cm}^{2}\right)$ and chlorophyll concentration $(\mathrm{mg})$ of leaves in different positions on the shoot is presented in Table 4. The total remaining leaf areas as well as chlorophyll concentrations of the apical, middle, basal and bunch leaves of the $33 \%$ and $66 \%$ defoliated vines were significantly less than those of the $0 \%$ defoliated vines, generally decreasing with increasing defoliation percentage. In spite of this, it is striking that the $\mathrm{CO}_{2}$ assimilation rate (A) of the leaves of the partial defoliation treatments was still comparable to or even higher in relation to that of the control vines. From this it is evident that all the leaves and especially the basal leaves of the partially defoliated vines were proportionally photosynthetically more active than those of the non-defoliated vines. The remaining leaves of the partially defoliated vines, therefore, compensated adequately for the loss of leaves provided that defoliation was not too severe (66\%). These results confirm those found when ${ }^{14} \mathrm{CO}_{2}$ was applied to the different leaves (Hunter \& Visser, 1988b). The higher total $\mathrm{CO}_{2}$ assimilation rate of the partially defoliated vines is particularly important because of the substantial contribution of especially the basal leaves to the developing berry during the entire growth season (Hunter \& Visser, 1988b, 1988c). It is, therefore, of utmost importance to create a suitable microclimate in the canopyinterior for maximum photosynthetic activity of especially the leaves on the lower half of the shoot.

Evidently, there is no consistent relationship between chlorophyll concentration and photosynthetic activity of the leaves used during this investigation (Table 5). The significant correlations found for the basal and bunch leaves would seem to 
TABLE 2.

The effect of defoliation and developmental stage of the vine on the assimilation number $\left(\mathrm{mg} \mathrm{CO}_{2} / \mathrm{mg}\right.$ chlorophyll/h) of leaves in different positions on the shoot.

\begin{tabular}{|c|c|c|c|c|c|c|c|c|c|c|c|c|c|c|c|c|}
\hline \multirow{2}{*}{ DEVELOPMENTAL STAGE } & \multicolumn{4}{|c|}{ BUNCH LEAVES } & \multicolumn{4}{|c|}{ BASAL LEAVES } & \multicolumn{4}{|c|}{ MIDDLE LEAVES } & \multicolumn{4}{|c|}{ APICAL LEAVES } \\
\hline & ${ }^{\star} 0$ & ${ }^{\star} 33$ & ${ }^{\star} 66$ & Mean & 0 & 33 & 66 & Mean & 0 & 33 & 66 & Mean & 0 & 33 & 66 & Mean \\
\hline Berry set & 1,20 & 2,07 & 2,75 & $2,01^{b}$ & 2,16 & 4,39 & 4,43 & $3,66^{a}$ & $\begin{array}{r}c \\
4,02^{c}\end{array}$ & $9,54^{\mathrm{a}}$ & $\begin{array}{r}b \\
6,83\end{array}$ & $6,80^{a}$ & 4,66 & 5,92 & 7,69 & $6,09^{\mathrm{a}}$ \\
\hline Pea size & 1,30 & 2,14 & 2,18 & $1,87^{b}$ & 1,40 & 3,47 & 3,32 & $2,73^{b}$ & $2,50^{d}$ & ${ }_{5,20}^{\mathrm{c}}$ & $4,70^{\mathrm{c}}$ & $4,13^{b}$ & 4,27 & 4,97 & 5,96 & $5,07^{b}$ \\
\hline Véraison & 1,62 & 1,97 & 2,17 & $1,92^{b}$ & 1,78 & 2,89 & 2,63 & $2,43^{b}$ & $2,19^{d}$ & $\begin{array}{r}d \\
2,66\end{array}$ & $2,51^{d}$ & $2,45^{c}$ & 3,48 & 3,42 & 4,13 & $3,68^{c}$ \\
\hline Ripeness & 2,50 & 3,33 & 3,80 & $3,21^{a}$ & 2,08 & 3,33 & 3,33 & $2,91^{b}$ & $2,08^{d}$ & $3,20^{d}$ & $3,34^{d}$ & $2,87^{c}$ & 3,76 & 4,34 & 4,89 & $4,33^{c}$ \\
\hline Mean & $\begin{array}{r}\mathrm{B} \\
1,66\end{array}$ & $\begin{array}{r}\text { A } \\
2,38\end{array}$ & $2,73^{A}$ & & $\begin{array}{r}\mathrm{B} \\
1,86\end{array}$ & ${ }_{3,52}^{A}$ & $\begin{array}{r}\text { A } \\
3,43\end{array}$ & & $\begin{array}{r}\mathrm{C} \\
2,70\end{array}$ & $\begin{array}{r}\mathrm{A} \\
5,15\end{array}$ & $4,34^{B}$ & & $\begin{array}{r}\mathrm{B} \\
4,04\end{array}$ & $\begin{array}{r}\mathrm{B} \\
4,66\end{array}$ & $\begin{array}{r}\text { A } \\
5,67\end{array}$ & \\
\hline CV (\%) & 37,47 & & & & 18,40 & & & & 18,71 & & & & 15,77 & & & \\
\hline
\end{tabular}

* Percentage defoliation

Values designated by the same letter do not differ significantly $(\mathrm{p} \leq 0,05)$ for each leaf position

TABLE 3.

The effect of defoliation and developmental stage of the vine on the specific leaf mass (fresh mass per leaf area, $\mathrm{mg} / \mathrm{cm}^{2}$ ) of leaves in different positions on the shoot.

\begin{tabular}{|c|c|c|c|c|c|c|c|c|c|c|c|c|c|c|c|c|}
\hline \multirow{2}{*}{ DEVELOPMENTAL STAGE } & \multicolumn{4}{|c|}{ BUNCH LEAVES } & \multicolumn{4}{|c|}{ BASAL LEAVES } & \multicolumn{4}{|c|}{ MIDDLE LEAVES } & \multicolumn{4}{|c|}{ APICAL LEAVES } \\
\hline & ${ }^{\star} 0$ & ${ }^{\star} 33$ & ${ }^{\star} 66$ & Mean & 0 & 33 & 66 & Mean & 0 & 33 & 66 & Mean & 0 & 33 & 66 & Mean \\
\hline Berry set & 17,85 & 18,79 & 17,15 & $17,93^{\mathrm{b}}$ & 16,98 & 19,48 & 17,97 & $18,14^{b}$ & 19,61 & 17,15 & 23,28 & $20,01^{b}$ & 18,40 & 20,16 & 20,24 & $19,60^{a}$ \\
\hline Pea size & 21,24 & 17,57 & 22,31 & $20,37^{\mathrm{a}}$ & 20,71 & 23,35 & 22,24 & $22,10^{a}$ & 22,73 & 23,49 & 23,69 & $23,31^{a}$ & 20,14 & 20,42 & 20,69 & $20,42^{a}$ \\
\hline Véraison & 20,02 & 21,42 & 20,26 & $20,57^{a}$ & 21,82 & 22,23 & 23,33 & $22,46^{a}$ & 22,88 & 22,71 & 24,55 & $23,38^{a}$ & 20,67 & 19,86 & 21,31 & $20,62^{a}$ \\
\hline Ripeness & 20,83 & 20,36 & 20,36 & $20,51^{a}$ & 21,87 & 21,54 & 23,04 & $22,15^{a}$ & 22,69 & 24,08 & 23,92 & $23,56^{\mathrm{a}}$ & 20,41 & 21,58 & 20,92 & $20,97^{a}$ \\
\hline Mean & $\underset{19,98}{A}$ & $\begin{array}{r}A \\
19,54\end{array}$ & $\begin{array}{r}A \\
20,02\end{array}$ & & $\begin{array}{r}A \\
20,35\end{array}$ & $\begin{array}{r}A \\
21,65\end{array}$ & $\begin{array}{r}A \\
21,64\end{array}$ & & \begin{tabular}{r|}
$B$ \\
21,98
\end{tabular} & \begin{tabular}{|r|}
$\mathrm{B}$ \\
21,86
\end{tabular} & \begin{tabular}{r|}
$A$ \\
23,86
\end{tabular} & & $\begin{array}{r}A \\
19,91\end{array}$ & $\begin{array}{r}A \\
20,51\end{array}$ & $\begin{array}{r}A \\
20,79\end{array}$ & 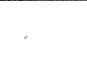 \\
\hline CV (\%) & \multicolumn{4}{|l|}{10,51} & \multicolumn{4}{|l|}{7,72} & \multicolumn{4}{|l|}{7,83} & \multicolumn{4}{|l|}{8,27} \\
\hline
\end{tabular}

* Percentage defoliation

Values designated by the same letter do not differ significantly $(\mathrm{p} \leq 0,05)$ for each leaf position

suggest that a relationship between chlorophyll concentration and photosynthetic activity exists only for interior-canopy mature leaves exposed to lower light conditions. It seems likely that factors such as the source: sink relationship, competition between leaves for mineral nutrients and hormones, feedback inhibition of photosynthesis by end products and enzymes involved with carboxylation in the chloroplasts as well as internal resistance to $\mathrm{CO}_{2}$ transfer between the intercellular spaces and $\mathrm{CO}_{2}$ fixing positions in the chloroplasts (Neales \& Incoll, 1968; Wareing et al., 1968), were probably more regulatory to photosynthetic activity than chlorophyll concentration and light intensity, although their involvement cannot be ignored. However, this needs further investigations.

\section{CONCLUSIONS}

Although changes in chlorophyll concentration corresponded to photosynthetic activity in certain cases, this relationship was not consistent. Therefore, chlorophyll concentration cannot be regarded as a reliable index for photosynthetic activity of grapevine leaves.

Because of the significant stimulation in photosynthetic activity of especially the remaining basal leaves of the par- 
TABLE 4.

The effect of defoliation on the total $\mathrm{Co}^{2}$ assimilation rate (A), (calculated on a total leaf area basis as $\mathrm{mg} \mathrm{CO} / \mathrm{h}$ ), total leaf area $\left(\mathrm{cm}^{2}\right)$ and total chlorophyll concentration $(\mathrm{mg})$ of leaves in different positions on the shoot.

\begin{tabular}{|c|c|c|c|c|c|c|c|c|c|c|c|c|}
\hline & \multicolumn{3}{|c|}{ BUNCH LEAVES } & \multicolumn{3}{|c|}{ BASAL LEAVES } & \multicolumn{3}{|c|}{ MIDDLE LEAVES } & \multicolumn{3}{|c|}{ APICAL LEAVES } \\
\hline & ${ }^{\star} 0$ & ${ }^{\star} 33$ & ${ }^{\star} 66$ & 0 & 33 & 66 & 0 & 33 & 66 & 0 & 33 & 66 \\
\hline $\begin{array}{l}\text { Leaf area } \\
\% \text { of control }\end{array}$ & $\begin{array}{r}a \\
234,13 \\
100,00\end{array}$ & $\begin{array}{r}b \\
199,72 \\
85,30\end{array}$ & $\begin{array}{r}\mathrm{C} \\
115,24 \\
49,22\end{array}$ & $\begin{array}{r}\mathrm{a} \\
783,15 \\
100,00\end{array}$ & $\begin{array}{r}b \\
500,37 \\
63,89\end{array}$ & $\begin{array}{r}\mathrm{c} \\
302,80 \\
38,66\end{array}$ & $\begin{array}{l}859,60^{a} \\
100,00\end{array}$ & $\begin{array}{r}b \\
585,77 \\
68,14\end{array}$ & $\begin{array}{r}\mathrm{C} \\
387,13 \\
45,04\end{array}$ & $\begin{array}{r}a \\
372,74 \\
100,00\end{array}$ & $\begin{array}{r}b \\
241,83 \\
64,88\end{array}$ & $\begin{array}{r}\mathrm{C} \\
148,58 \\
39,86\end{array}$ \\
\hline $\begin{array}{l}\text { Chlorophyll } \\
\% \text { of control }\end{array}$ & $\begin{array}{r}a \\
4,47 \\
100,00\end{array}$ & $\begin{array}{r}\mathrm{a} \\
3,71 \\
83,00\end{array}$ & $\begin{array}{r}b \\
2,24 \\
50,11\end{array}$ & $\begin{array}{r}\mathrm{a} \\
16,50 \\
100,00\end{array}$ & $\begin{array}{r}\mathbf{b} \\
10,66 \\
64,61\end{array}$ & $\begin{array}{r}\mathrm{C} \\
6,97 \\
42,24\end{array}$ & $\begin{array}{r}21,54 \\
100,00\end{array}$ & $\begin{array}{r}b \\
13,49 \\
62,63\end{array}$ & $\begin{array}{r}b \\
10,39 \\
48,24\end{array}$ & $\begin{array}{r}\mathrm{a} \\
8,82 \\
100,00\end{array}$ & $\begin{array}{r}b \\
6,19 \\
70,18\end{array}$ & $\begin{array}{r}\mathrm{C} \\
3,80 \\
43,08\end{array}$ \\
\hline $\begin{array}{l}\text { A } \\
\% \text { of control }\end{array}$ & $\begin{array}{r}a \\
18,71 \\
100,00\end{array}$ & $\begin{array}{r}a \\
23,14 \\
123,68\end{array}$ & $\begin{array}{r}\mathrm{a} \\
16,52 \\
88,30\end{array}$ & $\begin{array}{r}b \\
87,51 \\
100,00\end{array}$ & $\begin{array}{r}a \\
114,24 \\
130,55\end{array}$ & $\begin{array}{r}c \\
73,37 \\
83,84\end{array}$ & $\begin{array}{r}a \\
167,31 \\
10000\end{array}$ & $\begin{array}{r}a \\
180,20 \\
10770\end{array}$ & $\begin{array}{r}b \\
129,50 \\
77,40\end{array}$ & 100,31 & $\begin{array}{r}b \\
78,88 \\
78,64\end{array}$ & $\begin{array}{l}\mathrm{C} \\
58,32 \\
58,14\end{array}$ \\
\hline $\begin{array}{c}\text { CV (\%) : Leaf area } \\
\text { Chlorophyll } \\
\text { A }\end{array}$ & $\begin{array}{r}20,06 \\
26,81 \\
9,00\end{array}$ & & & $\begin{array}{r}15,71 \\
15,34 \\
4,76\end{array}$ & & & $\begin{array}{r}15,88 \\
25,79 \\
4,70\end{array}$ & & & $\begin{array}{r}15,30 \\
27,01 \\
4,92\end{array}$ & & \\
\hline
\end{tabular}

\section{* \% Defoliation}

Values designated by the same letter in a row do not differ significantly $(\mathrm{p} \leq 0,05)$ for each leaf position. Log transformations,to compensate for heterogeneity, were done on the raw A data.

TABLE 5.

Correlation coefficients ( $\mathrm{r}$ ) between rate of photosynthesis $\left(\mathrm{mg} \mathrm{CO}_{2} \mathrm{dm}^{2} / \mathrm{h}\right)$ and chlorophyll $a$ and $b$ concentration $(\mu \mathrm{g} / \mathrm{g}$ fresh mass).

\begin{tabular}{|c|c|c|c|c|c|c|c|c|}
\hline \multirow{2}{*}{$\begin{array}{c}\text { INDEPENDENT } \\
\text { VARIABLE }\end{array}$} & \multicolumn{2}{|c|}{ BUNCH LEAVES } & \multicolumn{2}{c|}{ BASAL LEAVES } & \multicolumn{2}{c|}{ MIDDLE LEAVES } & \multicolumn{2}{c|}{ APICAL LEAVES } \\
\cline { 2 - 9 } & ${ }^{+} \mathrm{C}_{\mathrm{a}}$ & ${ }^{+} \mathrm{C}_{\mathrm{b}}$ & $\mathrm{C}_{\mathrm{a}}$ & $\mathrm{C}_{\mathrm{b}}$ & $\mathrm{C}_{\mathrm{a}}$ & $\mathrm{C}_{\mathrm{b}}$ & $\mathrm{C}_{\mathrm{a}}$ & $\mathrm{C}_{\mathrm{b}}$ \\
\hline Rate of photosynthesis & $0,64^{*}$ & $0,58^{\star}$ & $0,63^{\star}$ & $0,59^{*}$ & 0,13 & $-0,30$ & 0,42 & 0,39 \\
\hline
\end{tabular}

$=$ Chlorophyll $a$ and $b$

* Significantly correlated at $\mathrm{p} \leq 0,05$

tially defoliated vines, it is a necessity to create a photosynthetically optimum microclimate in the canopy interior. However, the results propose that the excessive removal of metabolically active leaves must be avoided on the lower half of the canopy during the early developmental stages of the vine, and on the apical parts of the shoots from véraison to ripeness by for example severe topping during this period.

\section{LITERATURE CITED}

ANDERSON, P.C. \& BRODBECK, B.V., 1988. Water relations and net $\mathrm{CO}_{2}$ assimilation of peach leaves of different ages. J. Amer. Soc. Hort. Sci. 113, $242-248$.

ARNON, D.I., 1949. Copper enzymes in isolated chloroplasts. Polyphenoloxidase in Beta vulgaris. Plant Physiol. 24, 1-15.

BJÖRKMAN, O. \& HOLMGREN, P., 1963. Adaptability of the photosynthetic appara- tus to light intensity in ecotypes from exposed and shaded habitats. Physiol. Plant. 16, 889-914.

BOARDMAN, N.K., 1977. Comparative photosynthesis of sun and shade plants. Ann. Rev. Plant Physiol. 28, 355-377.

BUTTROSE, M.S., 1966. The effect of reducing leaf area on the growth of roots, stems and berries of Gordo grapevines. Vitis 5, 455-464.

GABRIELSEN, E.K., 1948. Effects of different chlorophyll concentrations on photosynthesis in foliage leaves. Physiol. Plant. 1, 5-37.

HESKETH, J.D., 1963. Limitations to photosynthesis responsible for differences among species. Crop Sci. 3, 493-496.

HODGKINSON, K.C., 1974. Influence of partial defoliation on photosynthesis, photorespiration and transpiration by lucerne leaves of different ages. Aust. J. Plant. Physiol. 1, 561-578.

HOFÄCKER, W., 1976. Investigations on the influence of changing soil water supply on the photosynthesis intensity and the diffusive resistance of vine leaves. Vitis 15, 171-182.

HOFÄCKER, W., 1978. Investigations on the photosynthesis of vines. Influence of defoliation, topping, girdling and removal of grapes. Vitis 17, 10-22.

HUNTER, J.J. \& VISSER, J.H., 1988a. Distribution of ${ }^{14}$ C-photosynthetate in the shoot 
of Vitis vinifera L. cv. Cabernet Sauvignon. I. The effect of leaf position and developmental stage of the vine. S. Afr. J. Enol. Vitic. 9 (1), 3-9.

HUNTER, J.J. \& VISSER, J.H., 1988b. Distribution of ${ }^{14} \mathrm{C}$-photosynthetate in the shoo of Vitis vinifera L. cv. Cabernet Sauvignon II. The effect of partial defoliation. $S$. Afr. J. Enol. Vitic. 9(1), 10-15.

HUNTER, J.J. \& VISSER, J.H., 1988c. The effect of partial defoliation, leaf position and developmental stage of the vine on the photosynthetic activity of Vitis vinifera L. cv. Cabernet Sauvignon. S. Afr. J. Enol. Vitic. 9(2), 9-15.

JOHNSON, J.O., WEAVER, R.J. \& PAIGE, D.F., 1982. Differences in the mobilization of assimilates of Vitis vinifera L. grapevines as influenced by an increased source strength. Am. J. Enol. Vitic . 33, 207-213.

KAPPEL, F. \& FLORE, J.A., 1983. Effect of shade on photosynthesis, specific leaf weight, leaf chlorophyll content, and morphology of young peach trees. J. Amer. Soc. Hort. Sci. 108, 541-544.

KLIEWER, W.M., 1980. Vineyard canopy management - a review. In: A.D. Webb (ed.): Grape and Wine Centennial Symp. Proc., pp. 342-352. University of California, Davis.

KLIEWER, W.M. \& ANTCLIFF, A.J., 1970. Influence of defoliation, leaf darkening and cluster shading on the growth and composition of Sultana grapes. Am.J. Enol.Vitic. 21, 26-36.

KLIEWER, W.M. \& NASSAR, A.R., 1966. Changes in concentration of organic acids, sugars and amino acids in grape leaves. Am. J. Enol. Vitic. 17, 48-57.

KOBLET, W., 1984. Influence of light and temperature on vine performance in coo climates and applications to vineyard management. In: Heatherbell, D.A., Lombard, P.B., Bodyfelt, F.W. and Price, S.F. (eds.): Proc. Int. Symp. on Cool Climate Vitic. Enol., pp. 139-157. Oregon State University, Oregon.

KRIEDEMANN, P.E., 1968. Photosynthesis in vine leaves as a function of light intensity, temperature, and leaf age. Vitis 7, 213-220.

KRIEDEMANN, P.E., 1977. Vineleaf photosynthesis. In: Proc. Int. Symp. on the Quality of the Vintage, pp. 67-87. 14-21 Feb. Cape Town.

KRIEDEMANN, P.E., KLIEWER, W.M. \& HARRIS, J.M., 1970. Leaf age and photosynthesis in Vitis vinifera L. Vitis 9, 97-104.

MACKINNEY, G., 1941. Absorption of light by chlorophyll solutions. J. Biol. Chem. 140, 315-322.

MACVICAR, C.N. \& Soil Survey Staff, 1977. Soil classification. A binomial system for South Africa. Scientific Pamphlet 390. Dep. Agric. Water Supply, Private Bag X116, 0001 Pretoria, Republic of South Africa.

MARINI, R.P. \& MARINI, M.C., 1983. Seasonal changes in specific leaf weight, net photosynthesis, and chlorophyll content of peach leaves as affected by light penetration and canopy position. J. Amer. Soc. Hort. Sci. 108, 609-613.

MAY,P., SHAULIS, N.J. \& ANTCLIFF, A.J., 1969. The effect of controlled defoliation in the Sultana vine. Am. J. Enol. Vitic, 20, 237-250.

NEALES, T.F. \& INCOLL, L.D., 1968. The control of leaf photosynthesis rate by the level of assimilate concentration in the leaf: A review of the hypothesis. Bot. Rev. 34, 107-125.

SCHAFFER, B., BARDEN, J.A. \& WILLIAMS, J.M., 1986. Net photosynthesis, dark respiration, stomatal conductance, specific leaf weight, and chlorophyll content of strawberry plants as influenced by fruiting. J. Amer. Soc. Hort. Sci. 111, 82-86.

SESTAK, Z., 1966. Limitations for finding a linear relationship between chlorophyl content and photosynthetic activity. Biol. Plant. 8, 336-346.

SHAULIS, N.J., AMBERG, H. \& CROWE, D., 1966. Response of Concord grapes to light, exposure and Geneva double curtain training. Proc. Am. Soc. Hort. Sci. 89, 268-280.

SMART, R.E., 1973. Sunlight interception by vineyards. Am.J. Enol.Vitic. 24, 141-147. SMART, R.E., 1974. Photosynthesis by grapevine canopies. J. Appl. Ecol. 11, 997 1006.

SMART, R.E., 1985. Principles of grapevine canopy microclimate manipulation with implications for yield and quality. A review. Am. J. Enol. Vitic. 36, 230-239.

WAREING, P.F., KHALIFA, M.M. \& THREHARNE, K.J., 1968. Rate-limiting processes in photosynthesis at saturating light intensities. Nature 220, 453-457.

ZEEMAN, A.S., 1981 Oplei. In: Burger, J.D. and J. Deist (eds.). Wingerbou in SuidAfrika, pp. 185-201. VORI, Stellenbosch, Republic of South Africa. 